\title{
Tomographic evaluation of the oropharynx
}

\author{
Oswaldo Vasconcellos Vilella ${ }^{a}$, Marcelo Godoy Queiroz ${ }^{a}$, Alexandre Oliveira Silva ${ }^{a}$, Beatriz Souza Vilella ${ }^{a}$
}

\begin{abstract}
Objective: To calculate the major constriction area of the oropharynx, using 3-dimensional images derived from cone beam computed tomography (CBCT), in order to: 1. Obtain normal level indexes according to the age group 2. Correlate the major constriction area of the oropharynx with its sagittal depth and its total volume.

Methods: Forty-one scans from the 3D-i-CAT computerized tomograph were evaluated by the software InVivoDental 5.0.

Results: The values of the major constriction areas of the oropharynx were obtained, related to the age. There was a positive strong correlation only for the oropharynx major constriction area and its total volume. The correlation between the oropharynx sagittal depth and its major constriction area was positive and moderate. In relation to its sagittal depth and its total volume, the correlation was positive and weak.

Conclusions: 1 . To the age group 6-12 years, the values ranged from 52.03 to $194.37 \mathrm{~mm}^{2}$; to 13-18 years, ranged from 134.82 to $264.18 \mathrm{~mm}^{2}$, and to the age group $>19$ years, from 95.87 to $229.73 \mathrm{~mm}^{2} ; 2$. The linear measurement of the sagittal depth of the oropharynx, as performed over lateral cephalometric radiographs, is not much reliable when compared to those achieved from tomographic images.
\end{abstract}

Key words: Oropharynx; cephalometry; tomography; constriction area; age.

\section{Avaliação tomográfica da orofaringe}

\section{Resumo}

Objetivo: Calcular a área de maior constrição da orofaringe, através de imagens tridimensionais obtidas de exames de tomografia computadorizada cone beam (TCCB), com o objetivo de: 1 . Obter índices de normalidade de acordo com a faixa etária; 2. Correlacioná-la com a sua profundidade e com o seu volume total.

Métodos: Foram estudados 41 exames obtidos através do tomógrafo computadorizado 3D-i-CAT, avaliados através do software InVivoDental 5.0.

Resultados: Foram obtidos valores correspondentes às áreas de maior constrição da orofaringe, de acordo com a faixa etária. A correlação entre a profundidade e a área de maior constrição da orofaringe mostrou-se apenas moderada, ao passo que entre sua profundidade e seu volume total apresentou-se fraca. Quando a área de maior constrição e o volume total foram comparados, observou-se forte correlação.

Conclusões: 1. Para faixa etária 6-12 anos, os valores variaram de 52,03 a 194,37 mm²; para a faixa 13-18 anos, de 134,82 a $264,18 \mathrm{~mm}^{2}$, e para faixa $>19$ anos, de 95,87 a $229,73 \mathrm{~mm}^{2} ; 2$. A medição linear da orofaringe, conforme realizada nas radiografias cefalométricas laterais, mostrou-se pouco confiável quando comparada com as medições obtidas de imagens tomográficas.

Palavras-chave: Orofaringe; cefalometria; tomografia; área de constrição; faixa etária. a Federal Fluminense University, Niterói (RJ), Brazil Correspondence:

Open Access 


\section{Introduction}

The pharynx is a tubular structure formed by membranes and muscles, located behind the larynx and the oral and nasal cavities. It is extended since the cranial base until the level of the sixth cervical vertebra and of the inferior edge of the cricoid cartilage. Its length varies from 10 to 14 centimeters and is divided in three parts: nasopharynx, oropharynx and hypopharynx. The oropharynx is the middle portion of the pharynx, where are located the palatine tonsils. It is coated by lymphoid tissue and communicates with the oral cavity for the isthmus, extending itself since second until the fourth cervical vertebra [1].

The effect of the respiratory function on the craniofacial development is being studied since much time ago, as it is of great importance to guide the diagnosis and the orthodontic treatment planning [2]. Alterations in the oropharynx airspace can provoke interferences in the growing face process, with harmful consequences. Malocclusions caused by the soft tissue pressure against the dentition can affect the tooth eruption and the dental arch form [3,4].

These alterations should be diagnosed and treated, since they can delay or provoke the relapse of the orthodontic treatment. They can also be responsible for serious respiratory disturbances, as the obstructive sleep apnea [5].

The cephalometric radiographs allow the establishment of normality reference indexes to the oropharyngeal space. Nevertheless, the reliability of these radiographs to evaluate the airways is limited, since they provide a 2-dimensional image of a 3-dimensional structure [3,5]. With the advent of the cone beam computerized tomography (CBCT), 3-dimensional images of the patients ' head and neck became possible, increasing the consistency of the orthodontic diagnosis [6]. The CBCT has been more and more used in dentistry, as it provides 3D images with lower radiation when compared with the conventional computed tomography [2].

In the present paper, the major constriction area of the oropharynx was calculated through 3-dimensional models obtained from cone beam cat scans, with the following aims:

1. To obtain normal level indexes according to the age group;

2. To correlate the major constriction area of the oropharynx with its sagittal depth and its total volume.

\section{Methods}

The present study was submitted to the local ethical research committee (filed under number 273/2010) and performed in accordance to its norms.

The material used consisted of cranial CBCT scans of Brazilian individuals of both genders. The scans were acquired through the 3D-i-CAT (ICU071072, Imaging Sciences International, Hatfield, PA, USA) computerized tomograph and processed through the software's own image capture scanner (2.0.21 Xoran Technologies, Ann Arbor, Mich, USA) to create a DICOM file. Image acquisition was performed in natural head position with the Frankfort horizontal plane parallel to the ground, and the patient was instructed to keep the mandible in centric occlusion to maximum intercuspation [2,7-9]. Although the position of the patient's head does not affect the accuracy of the skeletal measurements [10], it can influence the soft tissues evaluation [2]. The CBCT was obtained in the complete FULL 220-mm mode, where the scanner performs two rotations $(20+20$ seconds; 0.4 voxel $)$, allowing to scan the entire skul [7,11].

The 85 CBCT scans used in this study were acquired in the period between 2008 and 2011. Patients in this database were aged between 8 and 64 years, with 40 males and 45 females. The following exclusion criteria were applied: patients with hypertrophic palatine tonsils, cases treated with orthognathic surgery and images that evidenced the absence of part of the maxilla, mandible, or the upper border of the external acoustic meatus. Fourty-one exams remained: 18 male and 23 female, aged between 8 and 52. They were divided in three groups, according to the patients age.

The information obtained from DICOM file extension was entered into the InVivoDental 5.0 software (Anatomage, San Jose, CA, USA). With this program, three windows were opened with coronal, sagittal, and transverse multiplanar images, in the same position acquired by the tomograph. Using the reorientation tool, the images were positioned analogous to the patient's head posture to get a lateral cephalometric radiography. To obtain the Frankfort horizontal plane, the left anatomical porion $(\mathrm{Pol})$ and the right (Orr) and the left (Orl) orbital points were used as references. These three points were included in the same plane parallel to the ground.

The sagittal depth of the oropharynx was measured from the point $\mathrm{fl}$ - intersection of the oropharynx posterior wall and the line B-Go - to the point $\mathrm{f} 2$ - intersection of the tongue posterior border and the line B-Go - using the Ceph Tracing tool from the 3D Cephalometric Analysis. The objective was to reproduce a similar image to the lateral cephalometric radiograph (Figure 1).

With the skull positioned in a lateral view, the visualization was changed into volume rendering to obtain a 3-dimensional image of the upper air ways. By using the enable clipping tool with the gray scale filter, two parallel reference planes to the Frankfort horizontal plane were done to delimit the oropharyngeal space. The first one was traced at the posterior nasal spine level, and the second followed the tangent of the most inferior point of the third cervical vertebra. The airway volume tool was used to calculate the oropharynx major constriction area, as also its total volume (Figure 2).

\section{Statistical analysis}

To verify the error of the method, after a 15-day interval all the variable values of the 41 sample exams were checked again. To calculate the systematic error, a paired Student's $t$ test was used; for the random error, the Dahlberg test was used. 


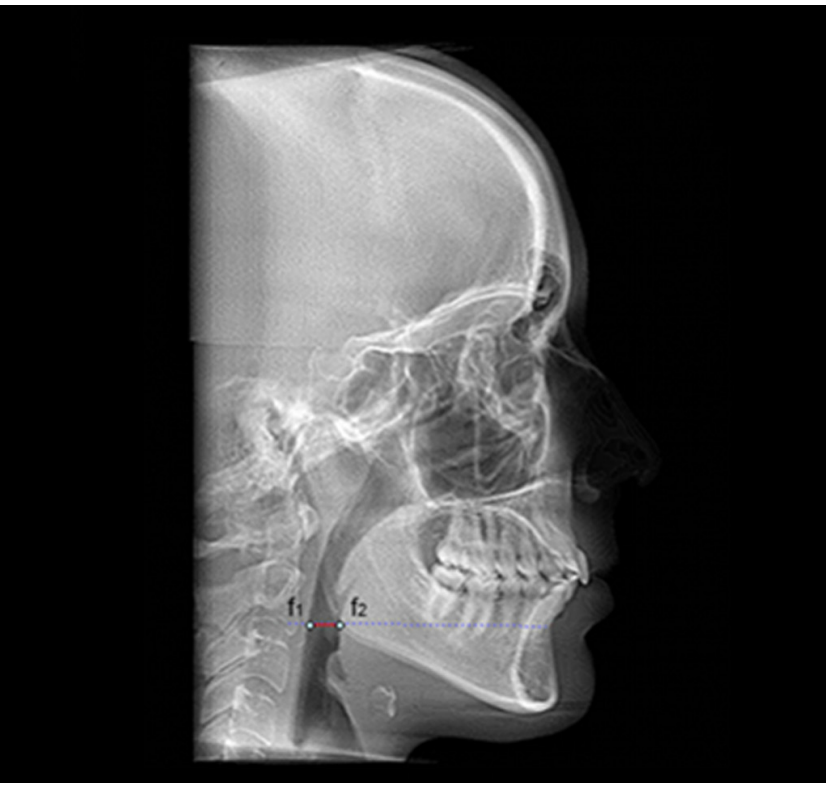

Fig. 1. Oropharinx sagittal depth, measured from $f_{1}$ to $f_{2}$

The Student's $t$ test was also used to assess the differences concerning the oropharynx major constriction area between the three age groups.

The Pearson's correlation coefficient ( $r$ ) was used to measure the strength and direction of the linear relationship between the studied variables. The coefficient of determination ( $\mathrm{r} 2$ ) measured the proportion of variability in the data set.

Microsoft Excel 2010 software was used to obtain the results of the statistical tests. A $5 \%$ probability $(p<0.05)$ significance level was adopted.

\section{Results}

There were no significant differences between the two measurement moments (Table 1). The intra-observer method error was, therefore, considered of little relevance in this study.

Means, standards deviations, means minus one standard deviation and means plus one standard deviation for the oropharynx major constriction area of the three age groups are presented in Table 2. The results showed increasing values between 6 and 12 and between 13 and 18 years of age, but for the age group $>19$ years there was a decrease.

The results showed in Table 3 suggest that there are statically significant differences concerning the oropharynx major constriction area between the three age groups.

Table 4 presents the correlation coefficient and the coefficient of determination values between the oropharynx major constriction area, its sagittal depth and its total volume. There was a positive strong correlation only for the oropharynx major constriction area and its total volume. The correlation between the oropharynx sagittal depth and its major constriction area was positive and moderate. In relation to its sagittal depth and its total volume, the correlation was positive and weak.

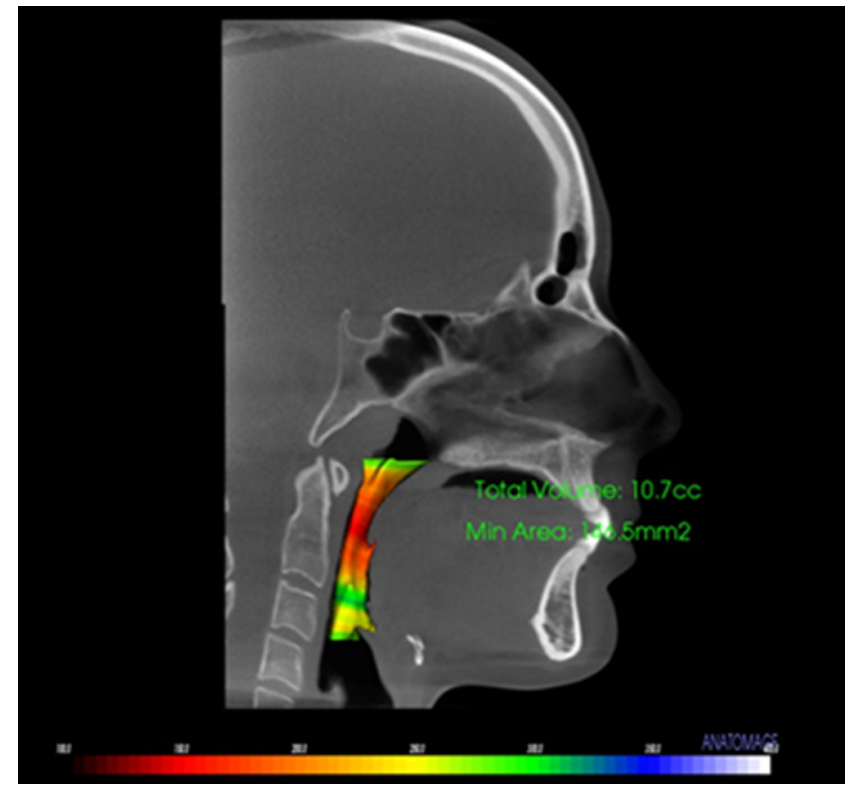

Fig. 2. Three-dimensional image of the oropharynx.

Table 1. Systematic error (p) and random error $(\alpha)$ of the method.

\begin{tabular}{l|ccc|c|c}
\hline \multicolumn{1}{c|}{ Variables } & Moments & $\overline{\mathrm{X}}$ & $\mathrm{SD}$ & $\boldsymbol{p}$ & $\alpha$ \\
\hline $\begin{array}{l}\text { Sagittal depth } \\
(\mathrm{mm})\end{array}$ & T1 & 10.60 & 2.82 & & \\
& T2 & 9.21 & 2.10 & 0.74 & 0.47 \\
Area & T1 & 156.24 & 73.54 & & \\
$\left(\mathrm{~mm}^{2}\right)$ & T2 & 155.85 & 73.82 & 0.98 & 3.54 \\
$\begin{array}{l}\text { Volume } \\
\text { (cc) }\end{array}$ & T1 & 11.66 & 4.19 & & \\
\hline
\end{tabular}

Table 2. Arithmetic means $(\bar{X})$, standard deviations (SD), means minus one standard deviation ( $\bar{X}-\mathrm{SD})$ and means plus one standard deviation $(\bar{X}+\mathrm{SD})$ related to the oropharynx major constriction area, in accordance to the age groups, in $\mathrm{mm}^{2}$.

\begin{tabular}{c|c|c|c|c|c|c|}
\hline \multirow{2}{*}{ Age group } & \multirow{2}{*}{$\mathbf{n}$} & \multicolumn{5}{|c}{ Oropharynx major constriction area } \\
\cline { 3 - 8 } & & Mean Age & $\overline{\mathbf{X}}$ & SD & $\overline{\mathrm{X}}$-SD & $\overline{\mathrm{X}}+\mathrm{SD}$ \\
\hline 6-12 years & 17 & 10y 09m & 123.2 & 71.17 & 52.03 & 194.37 \\
13-18 years & 11 & 15y 09m & 199.5 & 64.68 & 134.82 & 264.18 \\
>19 years & 13 & 31y 08m & 162.8 & 66.93 & 95.87 & 229.73 \\
\hline
\end{tabular}

Table 3. Statistical significance $(p)$ concerning the differences in the oropharynx major constriction area $\left(\mathrm{mm}^{2}\right)$ related to the three age groups.

\begin{tabular}{cccc}
\hline Group Age & $\bar{X}$ & SD & $p$ \\
$6-12$ & 123.21 & 71.17 & 0.01 \\
$13-18$ & 199.50 & 64.48 & \\
$6-12$ & 123.21 & 71.17 & 0.01 \\
$>19$ & 162.81 & 66.93 & \\
$13-18$ & 199.50 & 64,68 & 0.02 \\
$>19$ & 162.81 & 66.93 & \\
\hline
\end{tabular}


Table 4. Pearson's correlation coefficient $(r)$ and coefficient of determination $\left(r^{2}\right)$ between the oropharynx sagittal depth, its major constriction area and its total volume.

\begin{tabular}{lccc}
\hline \multicolumn{1}{c}{ Oropharynx } & $r$ & $r^{2}$ \\
Sagittal depth $\times$ area & 0.60 & $36.4 \%$ \\
Sagittal depth $\times$ volume & 0.46 & $21.3 \%$ \\
Area $\times$ volume & 0.84 & $70.4 \%$ \\
\hline
\end{tabular}

\section{Discussion}

The knowledge on the oropharynx normality characteristics is very important, as it allows to identify abnormal position of the tongue, besides respiratory problems as obstructive sleep apnea, which can influence the orthodontic treatment stability in the long stated period. In the past, the oropharynx sagittal depth was studied through lateral cephalometric radiographs, but this method presents the limitation to analyze a 3 -dimensional structure by means of 2-dimensional images. On the other hand, the cone beam computerized tomography (CBCT) allows a 3-dimensional analysis of the craniofacial skeleton, including the soft tissue. However, as it happens with all new technology, more studies are necessary to prove its benefits in relation to the conventional $\mathrm{x}$-rays already used in dentistry.

In studies involving quantitative variable measurement, the adequate assessment of their method errors is an important factor to be considered. It is believed that many cases should be replicated, as otherwise only large systematic errors could be identified. Even a relevant systematic error may be overlooked if an insufficient number of cases are used. There were no significant differences between the two measurement moments with respect to systematic error. Regarding the random error, the values found were small when compared to the mean values of the studied variables. Such results validated the methodology used in this research for data collection (Table 1).

As the air that feed the lungs is determined by the major constriction area of the oropharynx, sometimes constituted of a narrow corridor, we think that this passage is the variable to be considered in clinical practice. In other words, the mean point is the smallest area that will allow the airflow, and not the total volume of the oropharynx.

The results presented in Table 2 showed an increase in the oropharynx major constriction area until 18 years of age. After that, a small reduction occurred. This fact can be explained by the following way: the structures that compose the pharyngeal complex reach its bigger dimension between 14 and 18 years. Then the soft palate becomes longer and thick, occupying more space and diminishing the air passage $[13,14]$. It is interesting to notice that when the oropharynx was investigated through lateral cephalometric radiographs [4], an increase in its depth was observed in ages up 18. Therefore, the variation in the mass of the soft palate that occurs after age 18 seems to affect only its width and height, but not its sagittal extension.
Since the oropharynx dimensions vary with the patient's age $[4,12]$, the sample was divided according to the age groups. Our results confirmed such morphologic variations (Table 3). It is not valid, therefore, to use an average value for all the age groups.

The data collected for this research also demonstrated that the linear measurement of the oropharynx, as performed over lateral cephalometric radiographs, is not much reliable when compared with the measurements derived from tomographic exams (Table 4), and should be used with caution. Volume and area seem to be strongly correlated.

\section{Conclusions}

1. To the age group 6-12 years, the values of the oropharynx major constriction area ranged from 52.03 to $194.37 \mathrm{~mm}^{2}$; to 13-18 years, ranged from 134.82 to $264.18 \mathrm{~mm}^{2}$, and to the age group $>19$ years, from 95.87 to $229.73 \mathrm{~mm}^{2}$.

2. The linear measurement of the sagittal depth of the oropharynx, as performed over lateral cephalometric radiographs, is not much reliable when correlated to those achieved from tomographic images.

\section{References}

1. Alcazar NMPV, Freitas MR, Janson G, Henriques JFC, Freitas KMS. Estudo cefalométrico comparativo dos espaços naso e bucofaríngeo nas más oclusões Classe I e Classe II. Divisão 1, sem tratamento ortodôntico com diferentes padrões de crescimento. R Dental Press Ortodon Ortop Facial 2004;9:68-76

2. Kim Y, Hong J, Hwang Y, Park Y. Three-dimensional analysis of pharyngeal airway in preadolescent children with different anteroposterior skeletal patterns. Am J Orthod Dentofacial Orthop. 2010;137:306.e1-306.e11.

3. Grauer D, Cevidanes LS, Styner MA, Ackerman JL, Proffit WR. Pharyngeal airway volume and shape from cone-beam computed tomography: relationship to facial morphology. Am J Orthod Dentofacial Orthop 2009; $136: 805-14$

4. Nuernberg CHG, Vilella OV. Avaliação cefalométrica da orofaringe. Rev Odonto Ciência 2006;21:370-5

5. Iwasaki T, Hayasaki H, Takemoto Y, Kanomi R, Yamasaki Y. Oropharyngeal airway in children with Class III malocclusion evaluated by cone-beam computed tomography. Am J Orthod Dentofacial Orthop. 2009;136:318.e1-9.

6. Couceiro CP, Vilella OV. 2D / 3D cone beam CT images or conventional radiography: Which is more reliable? Rev Dental Press Ortodon Ortop Facial 2010;15:40e1-8

7. Moshiri M, Scarfe WC, Hilgers ML, Scheetz JP, Silveira AM, Farman AG. Accuracy of linear measurements from imaging plate and lateral cephalometric images derived from cone-beam computed tomography. Am J Orthod Dentofacial Orthop. 2007;132:550-60.

8. Cattaneo PM, Bloch CB, Calmar D, Hjorsthoj M, Melsen B. Comparison between conventional and cone-beam computed tomography-generated cephalograms. Am J Orthod Dentofacial Orthop. 2008;134:798-802.

9. Cevidanes L, Oliveira AE, Motta A, Phillips C, Burke B, Tyndall D. Head orientation in CBCT-generated cephalograms. Angle Orthod 2009;79:971-7.

10. Berco M, Rigali PH, Matthew M, DeLuca S, Anderson NK, Will LA Accuracy and reliability of linear cephalometric measurements from conebeam computed tomography scans of a dry human skull. Am J Orthod Dentofacial. 2009;136:17.e1-17.e9.

11. Farman A, Scarfe W. Development of imaging selection criteria and procedures should precede cephalometric assessment with cone-beam computed tomography. Am J Orthod Dentofacial Orthop. 2006;130:257-65.

12. El H, Palomo JM. Airway volume for different dentofacial skeletal patterns. Am J Orthod Dentofacial Orthop. 2011;139:511-21.

13. Johnston CD Richardson A. Cephalometric changes in adult pharyngeal morphology. Eur J Orthod. 1999;21:357-62.

14. Kollias I, Krogstad O. Adult craniocervical and pharyngeal changes a longitudional cephalometric study between 22 and 42 years of age. Part II: morphological uvulo-glossopharyngeal changes. Eur J Orthod 1999:21:345-355. 